\title{
Theoretical Review of Health Marketing and its Importance in the COVID-19 Pandemic
}

\author{
Revisión Teórica de la Mercadotecnia en Salud y su Importancia en la Pandemia de \\ COVID-19 \\ Diana L. Meza-Sánchez ${ }^{a}$, Ashly Y. Orozco-Rodríguez ${ }^{b}$, Elena G. Martínez-Acosta ${ }^{c}, \&$ Linda \\ M. Viramontes-Martínez ${ }^{d}$
}

\begin{abstract}
:
The contribution that marketing has made in the Health field is marked today more than ever by their psychosocial effects. From the dissemination of information to the appropriate use of technologies. This paper aims to present the most significant marketing elements focused on Health and how it influences the adherence to the Health authorities' strategies in the presence of the COVID-19. Elements of marketing and the essential components that may contribute to the pandemic control, behavioral change, and acquisition of protective behaviors are reviewed. Finally, an overhaul was made to describe deficiencies in healthy behavior acquisition and the factors or components that influence whether current campaigns will or will not have the expected impact on society. Marketing has theoretical and scientific evidence available that explains and exemplifies its influence on acquiring certain behaviors and the importance of making it evident in various fields, such as health, social, and labor.
\end{abstract}

Keywords:

Marketing, health, COVID-19, behavioral change, mental health

\begin{abstract}
Resumen:
La aportación que ha hecho el marketing en el ámbito de la Salud está marcada hoy más que nunca por sus efectos psicosociales. Desde la difusión de información hasta el uso adecuado de tecnologías. Este trabajo tiene como objetivo presentar los elementos de marketing más significativos enfocados en Salud y cómo influye en la adherencia a las estrategias de las autoridades de Salud ante la presencia del COVID-19. Se revisan los elementos de marketing y los componentes esenciales que pueden contribuir al control de la pandemia, el cambio de comportamiento y la adquisición de comportamientos protectores. Finalmente, se realizó una revisión para describir las deficiencias en la adquisición de conductas saludables y los factores o componentes que influyen en si las campañas actuales tendrán o no el impacto esperado en la sociedad. El marketing dispone de evidencias teóricas y científicas que explican y ejemplifican su influencia en la adquisición de determinadas conductas y la importancia de hacerlas evidentes en diversos campos, como el sanitario, social y laboral.
\end{abstract}

\section{Palabras Clave:}

Mercadotecnia, salud, COVID-19, cambio conductual, salud mental

\section{INTRODUCTION}

Health marketing's essence lies in being directly linked to the management of any health institution or service to provide quality and efficacy in their services. Such relation has as its primary objective the determination of a population's needs to achieve the desired level of satisfaction in a specific health service. That is why, today, health companies are more sensitive and aware of their users' needs, preferences, and expectations (Gongora, Escobar, Herrero, Sagaró, \& Pers, 2016).

Behavioral care is relevant, considering that health marketing implies addressing, expanding, and clarifying the information that requires immediate attention from different slopes and formats to produce some behavioral change or influence in a

\footnotetext{
${ }^{1 *}$ Diana L. Meza Sánchez, Autonomous University of the State of Hidalgo, https://orcid.org/0000-0002-4598-7561, Email: me246115@uaeh.edu.mx

${ }^{2}$ Ashly Y. Orozco Rodríguez, Autonomous University of the State of Hidalgo, http://orcid.org/0000-0003-1116-6658, Email: or362860@uaeh.edu.mx

Elena G. Martínez Acosta, Autonomous University of the State of Hidalgo, http://orcid.org/0000-0002-2295-787X, Email: ma354959@uaeh.edu.mx

${ }^{4}$ Linda M. Viramontes Martínez, Autonomous University of the State of Hidalgo, http://orcid.org/0000-0001-7268-0250, Email: vi356814@uaeh.edu.mx
} 
specific population. Such is the case of behavioral recommendations to prevent and reduce the SARS-CoV-2 pandemic (COVID-19).

Much has been said regarding health actions since the beginning and during the development of the COVID-19 pandemic. It is considering the objective of maintaining the society informed of its effects and ways to prevent the contagious. However, compared to all the provided information, little has been said about the psychosocial implications that health marketing has on the population, leaving aside immediate interventions to reduce physical or psychological symptoms caused by prolonged confinement (Suárez-Lugo, 2020). That is why this paper highlights some points to consider in the development of future health marketing proposals and marketing support tools to improve each subject's self-care behaviors.

\section{Marketing concept}

Today there are different terms that can cause confusion, when in fact they mean the same thing; such is the case with the use of the words marketing and its translation mercadotecnía in Spanish. According to the Royal Spanish Academy (2020), marketing refers to the set of principles and practices that seek to increase trade, especially demand. Marketing is defined as the effort to position a certain brand and/or product in the market through various strategies. In a broader sense, marketing is the process of planning and executing the conception and pricing, promotion, and distribution of ideas, goods, and services to create exchanges that can satisfy both individual and organizational goals. It uses a set of techniques and tools, which allow you to understand the market through research and analysis. Its basic premisesare, according to Adock (1993) are:

a) Identify the needs and wants of prospective potential customers

b) Smeet their needs

c) Rcarry out the exchange with the benefit for the seller as well as for the buyer

Marketing can only achieve full effectiveness if it fulfills the task of avoiding frustrations or dissatisfactions among consumers, since one of the biggest disappointments a consumer can have is not seeing their supply capacity transformed into an improvement in their quality of life (Corella, 1998).

\section{The new health conceptualization}

The World Health Organization (WHO) conceptualized health, as we first know it in 1946: "the state of complete physical, mental and social well-being, and not just the absence of disease." This definition has not changed, and it should be noted that it uses a scientific theoretical model called biopsychosocial, which recognizes that every individual has biological, psychological, and social dimensions. It considers the context in which they live and the social system in which they occur health/disease effects. That leads us to understand health as a complex process that requires the interaction of the person with the environment and the construction of healthy environments.

Having referred to the above, if marketing actions and strategies are taken to the field of health, it could then be said that "health marketing" would be explained as the "administrative orientation that consists of a process of exchange between client and professionals, to meet health needs and expectations" (Priego-Álvarez, 1995). As a management tool, marketing will have to locate unmet health needs, seeking to replace them with relevant services.

\section{Social marketing in health}

Marketing in health consists of two dimensions: Commercial and Social. The first has a purely economic interest. On the other hand, Social Marketing seeks to improve the quality of life under an ethical and collective approach that seeks to increase the acceptability of an idea and induce changes in behavior to improve people's lives. Social marketing aims to change or transform a harmful idea or behavior and adopt new ideas and behaviors (Burguete, 2004).

The strategies of social marketing in health are directed towards people who want or need a change or modification of behavior that puts their quality of life, well-being, and individual or collective security at risk and attempts to influence them to accept, modify or abandon certain conduct (Siegel, 2004). These strategies are a call to an integrated plan's individual and collective action, based on best practices of interventions oriented towards a collective benefit.

To generate voluntary behavior change through social marketing, the 4P's must be applied and mixed: Product, Price, Place, and Promotion (Carlo \& Luz, 2008).

As a product, the desired behavior and the benefits associated with it, services, and products that support or facilitate this change, the most important thing for a product is to show the real benefit for the group to which it is directed. The price refers to the personal cost in accepting the new behavior, which can be economical, although in most cases, it is intangible, psychological, emotional, or of time. The square is where the target audience goes and performs specific practices or spaces to learn the new behavior and the services associated with it. Finally, promotion consists of the integrated use of communication strategies and developing and defining the messages to be transmitted and the distribution channels.

Social Marketing in Health is a comprehensive strategy. It is based on the development of the 4 P's, whose purpose is to change behaviors, habits, and attitudes of the population to promote their health through the Promotion of Health and its Integrated Health Promotion Service, where social Marketing serves as a cross-cutting component that seeks to motivate individual and social actions and behaviors aimed at promoting health. Social Marketing in Health is based on the same commercial marketing techniques that allow the analysis and orderly and systematized knowledge of the product to be promoted (healthy behavior). The community (audience or 
target group to intervene) and the different variables that mediate between these two factors (individual, collective, environmental and cultural); design and disseminate messages, select channels, and manage and evaluate their impact to reinforce healthy habits and behaviors (Reyes, Garcia, \& Tellez, 2019).

\section{Communication process in health}

The social communication model in Mexico is, in its basic structure, an old model developed by public sector institutions, which, although it has been modernized, maintains as its central purpose to provide information to the population about the programs and actions that the institutions and agencies carry out, report on their achievements and disseminate them through the mass media: radio, television, and press. However, this communication occurs in a unidirectional way, that is, a single issuer issues it. With the incorporation of technological tools such as the Internet, the communicational return is promoted through blogs or social networks (Ministry of Health, 2010).

Returning to the Pan American Health Organization (2001), social communication programs in health must be based on understanding the needs and perceptions of the selected audiences, so this circular process consists of six stages, since the last one stage feed retrospectively to the first in a continuum of planning and refining. The social communication programs, according to the Pan American Health Organization (2001), are Stage 1: Planning and selection of strategies; Stage 2: Selection of channels and materials; Stage 3: Preparation of materials and preliminary tests; Stage 4: Execution; Stage 5: Evaluation of effectiveness and efficacy; and Stage 6: Feedback to refine (or not) the program.

Knowing these stages in the implementation of social communication programs in health allows having an organized format, which can generate a greater degree of effectiveness of the program's application in the face of problems. However, these programs are susceptible to modifications, according to the evaluations of effectiveness in its execution. Returning to Suarez, Hernández, Caján, Remoaldo, Torres, and Romero in 2016, who refers that knowledge of the marketing management processes will help prepare the content of educational activities better, also will give new reasons to develop programs in the field of Health.

For Bryant et al. (2001), health promotion interventions often lack an overall marketing plan and insufficient integration of its components to make the process genuinely strategic. Therefore, to generate a real impact on the Public Health of the population, according to Reyes, González, and Téllez (2019), the total intervention of the main actors is required: Government, institutions dedicated to providing health services in the States and above all participation of the community in general.
Social marketing is a methodology and management with multiple utilities that have become an indispensable tool for the effective and adequate approach to health promotion, prevention, communication, and intervention due to its impact and effectiveness (Góngora, 2014). Their knowledge and the way it is applied in practice constitute requirements of great relevance and priority if sought is to prevent, promote, and transform the aspects concerning the health-disease process and quality and life improvement. Finally, the conception of social marketing must be based on bioethics to optimize health personnel's work by generating an impact on health with a collective benefit.

\section{Technology as a useful tool in the face of the pandemic}

The use of technologies has long been a tool that has facilitated access to information and communication between people in different places. However, today, they have become an essential part of the monitoring of daily activities and the stimulation of recreational activities (Ciudades y Gobiernos Locales Unidos [CGLU], 2020).

Nevertheless, as the same author points out today more than ever, and thanks to the prevailing need for confinement, these tools have become an indispensable part of our lives.

As noted Digital Technologies and the COVID-19 pandemic (2020), as the coronavirus spreads worldwide, governments have placed significant restrictions on people's movement, the operation of services, and rules on distancing physical. In this context, technology can profoundly affect citizens' daily lives and guarantee them access to health services, access to information, and communication with the competent authorities, among other things.

That allows us to observe that in some cases, Information Communication Technologies (ICT's) facilitated activities that should have been canceled due to such circumstances, giving some possibility of adaptation. Such is the case of online classes, distance work, training, attention of all kinds by telephone or OnLine, congresses, workshops, among others. It is also important to mention that this has been true not in all cases since the presence of gaps in accessing or managing them could become a point against them. These situations make it impossible to continue with studies, work, or any other activity that requires it.

\section{Psychology y public health}

The understanding of the processes of acquisition of behavioral immunogens as mentioned by Matarazzo \& Istvan (1985) plays a fundamental role in psychology, specifically in the health-disease process, that is why this branch is used and specifically behavioral medicine, to reveal how beliefs, cognitions and emotions help reduce the spread of the spread of SARS-CoV-2. In this way, replicating them through health marketing is the most plausible and beneficial option.

They are Urzúa, Vera-Villarroel, Caqueo-Urízar and Polanco-Carrasco who offer us a first approach with their 
behavioral map of COVID-19 (2020) with behaviors that are perfectly measurable and identifiable, containing as main elements:
1. Hand washing
2. Avoid public contact
3. Social distancing
4. Use of masks
5. Respect quarantine if necessary

These five behaviors have proven to be more than necessary to flatten the contagion curve, and the general population must increase the frequency in which they are put into practice. That is why propagation through campaigns and health models are of vital importance.

According to Vera-Villarroel (2020), public communication is necessary today more than ever: messages, spokespersons from authorities, key actors, the example and opinion of political-social leaders, among others. Since these act as discriminative variables or models (vicarious learning) to change or influence the general population's behaviors.

Another point to consider this time within the area of beliefs is the illusory optimism reported by Raude et al. (2020) in the European population, which attributed the possibility of others getting sick much more likely than themselves. In other words, one's perceived risk was wholly underestimated. That allows us to observe the importance of identifying the cognitive distortions that may exist in the possibility of contagion and, in this way, direct the campaigns to combat them, demystifying and clarifying with the pertinent information.

Motivation refers to a critical pillar in acquiring and learning new behaviors (Cruz, Pérez, \& Cantero2009) and focuses on its maintenance over time. That can be achieved through extrinsic motivation, through mass broadcast messages, and intrinsic motivation, by promoting these behaviors' vision as a protective agent for oneself and the immediate environment (family and friends) extending to the most distal environment the general population.

Recent studies (Urzúa, Vera-Villarroel, Caqueo-Urízar \& Polanco-Carrasco, 2020) mention that interventions throughout the pandemic have been diverse. Some of them focus primarily on care in crisis due to the sudden change in activities or moving to a defined place where they are restricted for the most part. Besides, the traditional models of care have had to be modified to become OnLine care. Through this change, both psychologists and patients have had to adapt where tools and training for comprehensive health education are fundamentally provided, and social marketing had become a relevant tool.

The marketing campaigns that had been carried out to increase prevention are essentials considering that they can contribute to modified hazard behaviors that are of the interest of Public Health-increasing prevention into the performance of daily activities (Urzúa, Vera-Villarroel, Caqueo-Urízar \& Polanco-Carrasco, 2020).

\section{Behavioral biases}

According to Martinez, Rojas, and Scartascini (2020), behavioral biases are systematic deviations from rational behavior. Many of these may be interfering with decision-making that favors behavior change or the new acquisition of health behaviors during the pandemic crisis. The bias of the status quo or inertia that refers to maintaining the current state; cognitive overload, which is the amount of mental effort and memory used in a given time; social norms are those that are not written but that govern behavior within a society; overconfidence understood as the tendency to overestimate or exaggerate one's abilities; excess optimism is understood as the tendency to underestimate the probability of occurrence of adverse events; aversion to losses where the idea of a loss generates more discontent than the happiness that again would produce; availability heuristics that assess probabilities based on immediate examples; representativeness heuristic that refers to evaluating possibilities based on similarities between events and people; discomfort factors that are the inconveniences that hinder our decisions; temporal inconsistency where the tendency is to be impatient when choosing benefits today or in the future, in patients between benefits in two different periods in the future.

Similarly, the behavioral tools mentioned by Martinez, Rojas, and Scartascini (2020) are briefly mentioned, which are commonly used to counteract the cognitive biases described above:

a) Frame: Only the relevant part of the information (positive or negative) is highlighted.

b) Prominence: Make key aspects visible, use colors and typographic elements that are eye-catching, creative, and avoid the use of technicalities.

c) Default options: Use simple and direct words to avoid cognitive overload (for example: stay at home).

d) Commitment mechanisms: Restrict future alternatives to those that reflect long-term goals. Mitigate future impulsive behaviors.

e) Reminders: They can come in different ways; text message, mail, or personal visit to alert (for example, advertisements warning use of face masks, social distancing, epidemiological figures).

f) Micro Incentives: Rewards or punishments offered to influence behavior or decision.

g) Planning Tools: Encourage dividing the objective into smaller concrete tasks to anticipate unforeseen events.

h) Descriptive norms: They describe the behavior of a social group or community (for example, you may think that no one wears masks when the reality is that most do; promoting the norm of frequent use of masks can help improve individual behavior). 
i) Prescriptive norms: What society approves or disapproves of specific behavior. It is useful for reinforcing good behaviors and discouraging unacceptable ones.

j) Reciprocity: Social norm in which exchange in kind between people intervenes.

\section{Pandemic, covid-19 and its psychological effects}

Various countries at different times in humankind's history have presented disease outbreaks with rapid progress and a slow attention span, causing the disproportionate spread of the disease within their population and outside it, generating a pandemic.

Medina and Jaramillo-Valverde (2020) point out that COVID-19 is a disease caused by a new strain of the coronavirus that causes acute respiratory syndrome (SARS), which appeared in the Chinese city of Wuhan and spread rapidly around the world. During the presence of the SARS-CoV-2 virus and after confinement as the primary measure to prevent and reduce the spread of the disease, it has had an impact on physical, economic, social, psychological well-being, among others, where psychological well-being is altered not by a specific situation but for everything that entails prolonged confinement.

As indicated by the WHO (2020), the increase in depression and anxiety symptoms in various countries demonstrates the existence of some population groups prone to psychological discomfort. Such is the case of health personnel with more significant interaction with infected patients, an overload of work, contagion risk, or even decision-making about some patients' lives and death.

\section{DISCUSSIONS AND CONCLUSIONS}

The information provided by marketing shows a clear need to disseminate friendly, creative, and dynamic material for the target audience. These could be images, commercials, infographics, or other communication technologies. Likewise, they must contain information that counteracts those mentioned above behavioral and cognitive biases so that the adherence and acquisition of crucial behaviors can be consolidated as significant learning for the population.

For this, the implementation of ICT tools is widely suggested since they have demonstrated today, more than ever, their effectiveness in communicating with immediacy and efficiency, allowing the dissemination of relevant information, which is necessary to measure the importance of the acquisition of adaptive and beneficial behaviors for the population, in response to the needs that the current pandemic poses to us.

The task will fall on the shoulders of health personnel and health communication personnel since their expertise, coupled with training in psychoeducation or communication of these target behaviors, will maintain their health. They are crucial and objective of the approaches of social marketing in health.
A staff informed in how to make known the measures and precautions can strongly influence whether the conduct will be adopted by the patient (s). It is therefore essential that this aspect is taken into account for future interventions.

The behaviors that people have in different situations can influence the health-disease process, being so that while a particular part of the population acquires healthy behaviors that protect their integral well-being in the same way they are those who carry out risky behaviors. However, because there is little or no education in the face of these behaviors, infections could develop more frequently than expected by health authorities.

At some point during the pandemic and according to each person's characteristics, erroneous beliefs or behaviors could appear that could affect the person's well-being instead of benefiting him. All this is supported by the disclosure of false information that aims to obtain his benefit or alterations in society's structure generated behaviors of panic or uncertainty in the face of any present situation.

Urzúa, Vera-Villaroel, Caqueo-Urízar, and Planco-Carrasco (2020) state that going from a condition of absence of disease to being sick and even the success or not of the treatment will be determined by beliefs (cognitions), emotions (such as predispositions to action) and for behavior that is pro or risky for health. Likewise, the importance of taking into account two concepts, realistic optimism, and illusory optimism, can be rescued. The first is based on expecting positive things to happen, but with a criterion anchored to evidence and facts. In contrast, illusory optimism leads subjects to expect positive things, almost magically independent of what they do.

It can be identified that each of the characteristics of individuals can become a contribution to the prevention of risky behaviors taking into account the prevention of diseases or otherwise not doing something in the presence of apparent threats. For comprehensive health, and being influenced by each of the subjects' characteristics, the over the disease's information, either at the macro or micro level, produces these, in turn, stressors and deficient coping skills.

To counteract these negative consequences and of a psycho-emotional nature, the implementation and development of realistic messages are recommended, avoiding at all costs the implementation of high-impact sensational messages that aim to alarm the population (WHO, 2020).

In the same way, as indicated by the WHO (2020), specific regulations are suggested by official institutions in order to guarantee that those messages that are intended to be informative go through a systematic review, demonstrating their usefulness, effectiveness, public objective, and above all that the information provided is evidence-based.

It is recommended to have an approach to theoretical models in health intervention. Since the adaptation of these models to the needs and implications of social marketing in health would significantly increase the possibility of adherence to, which we can call based on their utility, behavioral immunogens 
(Matarazzo \& Istvan, 1985), those behaviors whose implementation and maintenance represent a protective factor to prevent the acquisition of COVID-19 (Rodriguez \& Londoño, 2010).

One of the models that can yield the most significant benefits would be the Precaution Adoption Process (PAP) proposed by Neil Weinstein and Sandman in 2002 - since it provides seven specific stages, divided into two criteria. Action one includes stages 6 and 7, in which we find the practice and maintenance of protective behaviors. Moreover, the cognitive processes that correspond to stages 1 to 5 show the beliefs and thoughts that the population has.

That is where health professionals' mission to adopt the proposals of health marketing to this model comes into play. To offer clear, truthful, and scientific information on protective behaviors that allow adapting behavior in the pandemic face, helping the correct acquisition of behavioral immunogens. So that not only does it result in a decrease in the contagion curve, but it also plays a fundamental role in the maintenance of these behavioral immunogens as this represents a significant advance in health, not only for the prevention of this specific strain but for others existing and future infections and viruses (Rodríguez \& Londoño, 2010).

\section{REFERENCES}

Adcock, D. (1993). Marketing: principles and practice. United States: Pitman Publishing.

Burguete, J. L. V. (2004). Pasado, presente y futuro de las dimensiones pública y social en el desarrollo conceptual del marketing. International Review on Public and Nonprofit Marketing, 1(1), 9-34. DOI: 10.1007/BF02896615.

Bryant, C., Lindenberger, J., Brown, C., Kent, E., Schreiber, J. M., Bustillo, M., \& Canright, M. W. (2001). A social marketing approach to increasing enrollment in a public health program: A case study of the Texas WIC program. Human Organization, 60(3), 234-246.

Caballero-Uribe, C., \& Alonso, L. (2008) Marketing en salud. Revista Salud Uninorte. 24(2), 1-3.

Ciudades y Gobiernos Locales Unidos. (2020). Experiencia de Aprendizaje en Vivo: Más allá de la respuesta inmediata al brote de COVID-19. Recuperado de https://www.uclg.org/sites/default/files/eng_briefing technology_es.pdf

Corella, J. (1998). Introducción a la gestión de marketing en los servicios de Salud. España: Salud pública y administración sanitaria. Navarra.

Cruz, N. M., Pérez, V. M., \& Cantero, C. T. (2009). Influencia de la motivación intrínseca y extrínseca sobre la transmisión de conocimiento. El caso de una organización sin fines de lucro. Revista de Economía Pública, Social y Cooperativa, (66), 187-211.
Góngora, G., Escobar, Y., Herrero A., Sagaró C., \& Pers, T. (2016). Aplicación de la mercadotecnia social en los servicios y programas de salud en Santiago de Cuba. Medisan, 20(4), 490-497.

Martínez, D., Rojas, A., \& Scartascini, C. (2020). La economía del comportamiento puede ayudar a combatir el coronavirus. Colombia: Banco Interamericano de Desarrollo BID. Recuperado de https://n9.cl/rigr.

Matarazzo, J., \& Istvan, J. (1985). Good and bad habits: the role of behavioral immunogens and pathogens in health and illness. Health and clinical psychology, 4 , 387-401.

Medina, R., \& Jaramillo-Valverde, L. (2020) El COVID-19: Cuarentena y su Impacto Psicológico en la población. Recuperado de https://preprints.scielo.org/index.php/scielo/preprint/ view/452/560.

Murueta, M. E. (2020). La salud psicológica en tiempos del coronavirus 19. Integración Académica en Psicología, 8 (23), 11-21.

Organización Mundial de la Salud. (2020). Aumentar sustancialmente las inversiones para evitar una crisis de salud mental. Recuperado de: https://n9.cl/tahdj.

Organización Mundial de la Salud. (2020). Gestión de la infodemia sobre la COVID-19: Promover comportamientos saludables y mitigar los daños derivados de la información incorrecta y falsa. Recuperado de https://n9.cl/i5th.

Organización Mundial de la Salud. (1948). En Basic Documents. Italy: World health organization constitution. Recuperado de https://apps.who.int/gb/bd/PDF/bd48/basic-document s-48th-edition-en.pdf.

Priego-Álvarez, H. (1995). ¿Por qué cliente y no paciente en los servicios de salud? Salud Pública de México. $37(5), 381-382$

Priego, H. (2015). Mercadotecnia en salud. Aspectos básicos y operativos. Tabasco: Red Iberoamericana de Mercadotecnia en Salud, A.C.

Raude, J., Debin, M., Souty, C., Guerrisi, C., Turbelin, C., Falchi, A., \& Duggan, J. (2020). Are people excessively pessimistic about the risk of coronavirus infection? Doi: 10.31234/osf.io/364qj

Real Academia Española. (2020). Definición de mercadotecnia. Recuperado de https://dle.rae.es/mercadotecnia.

Reyes, M., González, J. \& Téllez, M. (2019). Estrategias de Marketing social en salud: Análisis comparativo Nuevo León-Tabasco. Vincula Tégica EFAN, 5(1), 312-325.

Rodríguez, I., \& Londoño, C. (2010). El proceso de adopción de precauciones en la prevención secundaria del 
consumo de cigarrillos en estudiantes universitarios. Acta Colombiana de Psicología, 13(1), 79-90.

Secretaria de Salud. (2010). Manual de Mercadotecnia Social en Salud. Recuperado de https://n9.cl/mws22.

Suárez-Lugo, N. de la C. (2020). Mercadotecnia social en la prevención y control de la pandemia del coronavirus. Horizonte Sanitario, 19(3), 307-309. https://doi.org/10.19136/hs.a19n3.3925

Suarez, N., Hernández, C., Caján, M., Remoaldo, P., Torres, C., \& Romero, H. (2016). Conocimientos y actitudes hacia la mercadotecnia en salud en países de Iberoamérica. Revista Cubana de Salud Pública, 42, (1), 115-128.

Urzúa, A., Vera-Villarroel, P., Caqueo-Urízar, A., \& Polanco-Carrasco, R. (2020). Psicología en la prevención y manejo del COVID-19. Aportes desde la evidencia inicial. Terapia psicológica, 38(1), 103-118.

Vera-Villarroel, P. (2020). Psicología y COVID-19: un análisis desde los procesos psicológicos básicos. Cuadernos de Neuropsicología, 14(1), 10-18. DOI: 10.7714/CNPS/14.1.201 